\title{
Bir Milyar Ayaklanıyor
}

\author{
Bahar Gürey ${ }^{1}$
}

$\ddot{\boldsymbol{O}}$.

Bu çalışma, 14 Şubat 2013 Sevgililer Günü’nde kadına yönelik şiddete karşı küresel çapta yürütülen kampanyanın Ankara ayağının oluşma sürecini, gönüllülerin sosyal medya üzerinden bir araya gelişini, yapılan işbölümünü, bulunan sponsorları, etkinliğe katılanlarl, etkinlik sürecini, etkinlik sonrası yapılan değerlendirme çerçevesinde ele alarak kadına yönelik şiddete farkındalık oluşturmak amacıyla yapılmıştır. Çalışmada hedeflenen diğer kazanımlar, kadına yönelik şiddetin her geçen gün arttığı ve her üç kadından birinin şiddet gördüğ̈̈ ya da tecavüze uğradı̆̆ günümüz dünyasında, şiddete maruz kalan kadınlara yönelik farkındalı yaratmak, kadınların bir araya gelmesini sağlamak ve birlikte düşünerek çözüm sunmak biçimindedir. Bu farkındalık kampanyası, V-Day hareketinin "One Billion Rising” (Bir milyar ayaklanıyor) adıyla düzenlediği kampanyada dünya genelinde eş zamanlı dans etme eylemini merkeze almıştır. Bu kampanyaya erkeklerin ama özellikle kadınların katılması önemsenmiștir. Kampanyanın Ankara ayağı sosyal medya üzerinden (Facebook aracılığı ile) bir araya gelen yaklaşık on kişilik bir grup tarafindan, gönüllülü̈k esasına dayalı olarak gerçekleştirilmiştir.

Kampanya sonrast yapılan değerlendirme toplantısl, etkinliğe gelip duygularını yazarak ifade eden her yaştan ve sosyo-ekonomik sınıftan kadının, şiddete maruz kaldığını ortaya çıkarmıştır. Karanfil Sokak'ta gerçekleştirilen etkinlik, yaklaşık 4000 kişi tarafindan izlenmiştir. Etkinlikte, koreografiyi öğrenip dans edenlerin yanı sıra, o gün yalnızca izleyici olan katılımcıların da dans ettiği ve yaşadıkları şiddet olaylarını anlattıkları ve oyundan doğaçlamaya gidilerek hazırlanan performansların farkındalık açısından insanlar üzerinde etkili olduğu görülmüştür. Bildiride "Bir milyar ayaklanlyor" etkinliğinin hazırlık, eylem süreci ve değerlendirilmesi betimlenmiş̧tir.

Anahtar Sözcükler: "Bir milyar ayaklaniyor”, Dans, Şiddet, Kadın, Oyun, Drama, Tiyatro

\section{One Billion Rising}

\begin{abstract}
In this study, in February 14, 2013 Valentine's Day, The formation of Ankara base process for the campaign conducted on a global scale against the violence against women; volunteers coming together through social media, the division of labour, sponsors which are present, the participants of the event, what happened in the event, were handled within the framework of the content of post-event evaluation and dance.

The aim of the study is to raise awareness for women exposed to violence and provide women with the idea of coming together to provide solutions, in the world which the violence against women is increasing day by day and one in three women are raped or are subject to violence. In V-Day movement's campaign organized under the name "One Billion Rising", dances were performed around the world. Men and -particularlywomen participated in this campaign. Ankara base of the campaign was carried out on a voluntary basis by a group of about ten people which came together through social media (Facebook). In the evaluation meeting held after the campaign revealed that the women of all ages and socio-economic class, who participated and who expressed their feelings by writing were exposed to violence. Event was visited by about 4,000 people. During the event, it was observed that, in addition to the dancers who learned choreography, the participants who were only the audience that day also danced and they talked about their experiences of violence and the performance prepared by going to the game to improvisation was effective on people in terms of awareness. "One billion Rising" event's dance rehearsals, meeting notes, videos and photographs of the day are presented in the statement.
\end{abstract}

Keywords:"One Billion Rising", Dance, Violence, Women, Game, Drama, Theatre

1 Ankara Üniversitesi Yaratıcı Drama Yüksek Lisans Öğrencisi. Melek Hatun Mah. Elif Lamet Sok. Elif Apt. No:5/17 Şehremini /ISTANBUL Eposta: bagurey@hotmail.com Mobil Tel: 05388657808 


\section{Giriş}

“One Billion Rising” (Bir Milyar Ayaklanıyor); kadınlara ve kız çocuklarına yönelik şiddete karşı farkındalık yaratmak amacıyla, kadınlar tarafından yürütülen dünya çapında bir kampanyadır. 5 yaşında, 16 yaşında evi terk edene kadar babasının cinsel tacizine uğrayan ödüllü tiyatro oyunu Vajina Monologları'nın yazarı Eve Ensler tarafından 1998 yılında, kadınlara yönelik şiddete karşı uluslararası bir eylem olan "V-Day" hareketi kurulmuştur V-Day; zafer, sevgililer günü ve vajina kelimelerini temsil etmektedir. -Eve Ensler, 2012 yılından beri One Billion Rising adıyla kadın ve kız çocuklarının yaşadığı şiddete karşı dünya çapında bir kampanyaya öncülük etmektedir. ${ }^{2}$ Tüm dünyada ses getiren kampanyanın çağrısını V-Day şöyle özetlemektedir:

"Her üç kadından birinin şiddete maruz kaldığı istatistiğini hesapladı̆̆ınızda, dünyada bir milyarı aşkın kadının şiddetten etkilendiğini görürsünüz. V-Day'in 15. yıl dönümünde bir milyar kadını ve onlara değer verenleri bu şiddete son vermek için sokağa çımaya, yürümeye, dans etmeye ve taleplerini yükseltmeye çă̆ırıyoruz. V-Day, kolektif gücü ve sinırlar ötesi dayanışmayı tüm dünyanın görmesini istiyor.”

V-Day hareketine göre bu küresel bir direniş; kadınlara ve erkeklere tecavüz ve tecavüz kültürü sona erene kadar statükoyu reddetmeleri için bir çağrı, kadınların mücadelesinde bir dayanışma hareketidir. Aynı zamanda, kadın ve klz çocuklarına yönelik şiddetin kabulüne isyan, yeni bir zaman ve yeni bir varoluş biçimidir. "’3

"Bir milyar kadının haklarının ihlal edilmesi gaddarlıktır. Bir milyar kadının dans etmesiyse devrimdir." sloganıyla V-Day, "Bir milyar ayaklanıyor" kampanyasına çağrı yapmıştır. Bu çağrıyla kampanyaya katılan tüm ülkeler yalnızca bir şehirde değil, birden çok şehirde 14 Şubat 2013 Sevgililer Günü'nde, Debbie Allen'ın koreografisi ile sözleri Tena Clark'a, müziği Tena Clark ve Tim Heintz'e ait ortak bir şarkı eşliğinde dans etmişlerdir.

Kampanyada dans edilmesinin gerekçesini, devrimin bedenle başlaması düşüncesi oluşturmuştur. Bedenin estetik olarak kendini ifade etmesine olanak tanıyan dans, devrimin ilk adımını oluşturmaktadır. "Bir Milyar Ayaklanıyor” dans koreografisi, kampanyanın şarkı sözlerinde yer alan "kır zincirlerini" ifadesi sırasında dans eden katılımcıların ellerinde görünmeyen zincirleri dizlerine vurarak kırma devinimini içermektedir. Düşünce ve eylemi birleştirerek en etkili anlatım yolunu amaç edinen koreografide her hareketin bir anlamı vardır. Kadınlar zincirlerini kırarak özgürlüklerine kavuşmakta, devrimi dans ederek gerçekleştirmekte ve Kızıl Emma'ya atıfta bulunmaktadırlar: "Dans Edemeyeceksem Bu Benim Devrimim Değildir" (Goldman, 2006).

Türkiye'nin de bu çağrıya yanıt vererek, kampanyaya katılan ülkeler arasında yer almasında, ülkemizde konuya ilişkin durumun duyarsız kalınamayacak biçimde olması belirleyici olmuştur. Sözgelimi “Kadın Cinayetlerini Durduracağız Platformu”na göre, yalnız Türkiye'de 2008-2012 yılları arasında 700 kadının hayatına son verilmiştir. $\mathrm{Bu}$ kadınlar çoğu eşlerinden boşanmak istedikleri için öldürülmüşlerdir. 2013 yılı Ağustos ayı itibariyle 150 kadın, şiddete boyun eğmeyip, kendi hayatlarını yaşamak istedikleri için cinayete kurban gitmişlerdir. Ağustos ayında 26 kadın öldürülmüştür. Cinayetler artarken kadına uygulanan şiddette artış gözlenmiştir. ${ }^{4}$ Aile ve Sosyal Politikalar Bakanlığı, cinayetlerin azaldığını söylerken kadınlar öldürülmeye devam etmektedir.

Genellikle namus cinayetleri adı altında işlenen kadın cinayetleri, erkek hegemonyasının kadın üzerindeki yargısız infazının bir sonucudur. Kadın cinselliğinin ve doğurganlığının denetimi, Türkiye

2 http://de.wikipedia.org/wiki/Eve_Ensler, Erişim Tarihi: 25.10.2013

3 http://hurarsiv.hurriyet.com.tr/goster/printnews.aspx?DocID=22580904, Erişim Tarihi: 25.10.2013

4 http://www.kadincinayetlerinidurduracagiz.net/veriler/All, Erişim Tarihi: 28.10.2013 
üzerinde namus adı altında gerçekleştirilmekte ve kadın, erkek tarafından kontrol edilmektedir. Namus adı altında ortaya çıkan değerler yalnızca kadınlar üzerinden yürütülmektedir. Erkeğin koruması gereken namusu, eşinin, kızının, kız kardeşinin namusudur. Bu korunma kadınları eve kapatmakta, pasifize etmekte ve kadınların potansiyellerini keşfedememelerine ve gerçekleştirememelerine sebep olmaktadır. Kadınlar, toplumsal cinsiyet şiddeti altında ezilmektedirler. Fakat son yıllarda kadınlar sahip oldukları gücün farkına varmaya ve erkeğe, devlete karşı direnmeye başlamışlardır. Kadın cinayetlerine dur demek için kurulan platformların, sivil toplum kuruluşlarının ve eylemlerin yanı sıra "Bir Milyar Ayaklanıyor" kampanyasının da katkı sağlayacağı düşünülmüş; İstanbul, Ankara, İzmir başta olmak üzere Türkiye'nin birçok şehrinde organizasyonlar düzenlenmiş; kadınlar ve erkekler sokaklarda, meydanlarda ve parklarda birlikte dans etmişlerdir.

$\mathrm{Bu}$ çalışmada Ankara için sosyal medya üzerinden bir araya gelen bağımsız gönüllülerin kampanya sürecini betimlemek konu edilmiştir. Birbirini tanımadan bir araya gelerek oluşturulan bu grubun tek ortak paydası; kadına, kız ve erkek çocuklarına, LGBTİ bireylerine uygulanan her türlü şiddete, enseste, tecavüze karşı olmak ve bu şiddetin ortadan kalkması için birlikte mücadele etmektir.

\section{Yöntem}

\section{Etkinlik Hazırlığı}

Sosyal medya üzerinden ilan edilen kampanya etkinliği hakkında bilgi edinen ve konuya ilgi duyan kişiler, Facebook aracılığı ile "Bir milyar ayaklanıyor! Kadınlar için Diren Dans Et Ayaklan! One Billion Rising Ankara” sayfasına katıldılar. Bir süre etkinlik sayfası üzerinden yazıştıktan sonra, 08.01.2013 tarihinde bir toplant yapmaya karar verdiler. 12.01.2013 tarihinde ilk toplant1larını Aylak Madam'da gerçekleştirdiler. Bu toplantıya yalnızca beş kişi katıldı. İlk toplantıda kampanyanın Ankara ayağının yapılması konusu tartışıldı. Organizasyonun başlatılmasına karar verildi. Toplantı tutanağ1 tutuldu.

İlk toplantıda alınan kararlar arasında; belediyeden Karanfil Sokak’ta gerçekleştirilecek etkinlik için izin alınması, dans provalarının Hacettepe Üniversitesi'nin salonlarında yapılması için organize edilmesi, afiş ve broşür için fiyat alınması, Kaos GL ve Pembe Hayat ile irtibata geçilmesi, 1BR logolu, 14 Şubat 2013 Ankara yazılı beyaz polarların tasarlanması, görünmeyen malzeme listesi, kampanyanın Ankara ayağının Türkçe olarak sosyal paylaşım web sitesi olan Facebook'ta organizasyon grubu olarak açılması ve organizasyonda gönüllü çalışmak isteyenlerin bu gruba dâhil edilmesi yer ald1.

İlk buluşma sonrası sosyal medya üzerinden organizasyonda çalışmak isteyenlere yönelik bir sayfa açıldı. Bu sayfanın toplamda 109 üyesi vardı ve sayfada, iş bölümü sonrası yapılan çalışmalar hakkında bilgi verildi. Toplantı yapılmadığı zamanlarda iletişim bu organizasyon sayfası üzerinden sağlandı. İkinci toplantıya kadar, etkinliğin sosyal medya üzerinden sürekli duyurusu yapıldı; beyaz polarlar için baskı önerileri sunuldu. Oylama ile baskı seçildi. 120 Sivil Toplum Kuruluşu'na mail atıldı. Afiş önerileri sunuldu. Facebook için kapak fotoğrafi hazırlandı. Belediyeden izin alındı. Örnek afiş hazırlandı. CHP Ankara milletvekili Aylin Nazlı Aka ile görüşüldü. Kampanya günü konuşma yapması ve dans etmesi kesinleşti. 
17.01.2013 akşamı yine Aylak Madam'da ikinci buluşma için toplanıldı. Bu toplantıya katılım ilk buluşmanın neredeyse üç katıydı. Her gönüllü önce kendini tanıttı, sonra nasıl yardımcı olabileceğini anlattı. İş bölümü yapıldı. One Billion Rising resmi sayfası için toplu fotoğraf çekildi. Toplantı tutană̆ 1 tutuldu.

İkinci toplantıda alınan kararlar arasında; Azin Mokhtari ile kampanya organizatörlerinin yüzlerine yanık izi ya da yara makyajı yapılması için görüşülmesi, yaratıcı drama ile iki kısa performansın hazırlanması, kampanyaya davet için çağrı metninin yazılması yer aldı.

İkinci toplantının ardından gruptan bir kişi KAOS GL ile görüştü. Otuz saniyelik bir video çekildi ve bu video sayfalarında yayınlandı. ASSA (Ankara Sine-i Sanat Atölyesi) etkinliğe destek olacağını belirtti. Basın bülteni oluşturuldu. Avukat gönüllülerimiz Gelincik Merkezi ile görüştü. 20 Ocak 2013 tarihinde dans provaları için duyuru başladı. ODTÜ destekçimiz olacağını dile getirdi. Fakat emniyetten izin alınamadı. Belediye, etkinliği Kuğulu Park ile birleştirmek istedi. Bu öneri gönüllüler tarafindan kabul edilmedi. 24 Ocak 2013 tarihinde "Bir Milyar Ayaklanıyor" Ankara Karanfil Sokak’ta etkinliğine katılacakların sayısı Bir Milyar Ayaklanıyor Türkiye etkinliğinin katılımcı sayısından daha fazlaydı.

26.01.2013 akşamı Aylak Madam'da üçüncü toplantı yapıld1. Ancak bu toplantı sömestr tatiline rastladığı için toplantıya altı kişi katılabildi. ASSA da toplantıya katılanlar arasındaydı. Nasıl katkı sağlayabileceklerini anlattılar. Simurg Kuşu, canlı heykel performansı (Adalet Tanrıçası Themis, çok kollu kadın), barış işareti olan bez afiş, film skeçleri gibi alternatifleri sundular ve etkinliğin duyurulması için kendi sayfalarından duyuru yapacaklarını ve alınması gereken izinler için destek vereceklerini söylediler.

Üçüncü toplantıda alınan kararlar arasında, dans provalarının başlangıç gününün ve saatinin belirlenmesi, 7 kişinin emniyetten izin alması için karakola gitmesi, içinde şiddet kelimesinin geçmediği sloganların üretilmesi, Simurg kuşunun ağzına asılan mor kurdelelere, etkinliğe gelenlerin yazı yazıp iğneyle tutturması yer aldı.

Üçüncü toplantının ardından farklı yaş gruplarından kadınların katıldığı dans provaları başladı. 29-31 Ocak, 1-2, 6 Şubat 2013 tarihlerinde provalar Hacettepe Üniversitesi Sihhiye Kampüsü’ndeki salonlarda, belirlenen saatlerde, Hacettepe Üniversitesi Dans Topluluğu'nun eğitmenleri eşliğinde gerçekleştirildi. 3 Şubat 2013 tarihinde One Billion Rising, resmi sayfası için Ankara'nın videosu hazırlandı ve resmi sayfada yayınland.

28 Ocak 2013 günü yoğun ziyaretler gerçekleştirildi. Çankaya Belediyesi ile yapılan olumlu görüşme sonrası, pankart ve el ilanı için destek sözü verildi. Emniyetle yapılan görüşmede gerekli izin alındı. Emniyet görevlileri, etkinliğe eşleriyle birlikte katılacaklarını; Toplum Gönüllüleri Vakfı (TOG) organizasyona ne şekilde yardım edecekleri konusunda toplantı alarak geri dönüş yapacaklarını; Türk Mühendis ve Mimar Odaları Birliği (TMMOB) ise organizasyondan haberdar olduklarını ve dans ederek destek vereceklerini bildirdiler. Makine Mühendisleri Odası, 150 adet A3 afiş bastırma sözüyle destek verdi. ODTÜ Mezunlar Derneği ziyaret edildi. Destek vermekten mutluluk duyacaklarını dile getirdiler. Organizasyon grubundan gönüllüler milletvekillerine verilecek davetiyeleri yazdilar.

7 Şubat 2013 tarihinde afişleme başladı. Afişlemeye yardımcı olan erkek gönüllüler, afişleme sonrası afişlerin fotoğraflarını çekerek Facebook sayfasında paylaştılar. Tüm afişleme bir gün içinde tamamlandı. El ilanları basıldı. 9 Şubat 2013 itibariyle el ilanları farklı bölgelerde dağıtılmaya 
başlandı. 13 Şubat akşamı kalan el ilanları son dans provasından sonra tüm Kızılay, Sıhhıye ve civarında dağıtıldı.

10 Şubat 2013 akşamı İkarus’ta toplantı alındı. Son toplantıda 20 kişiden fazla gönüllü vardı. Etkinliğe son dört gün kala kimin hangi görevi üstleneceği tüm detaylarıyla görüşüldü. Pankart hazırlanmak amacıyla toplantı esnasında herkesten para toplandı. Alınan malzemelerin ne kadar tuttuğu daha sonra organizasyon sayfasından duyuruldu. Toplantı tutanağı tutuldu. Tutanağa göre verilen kararlar arasında; 11 Şubat 2013 Pazartesi günü yaratıcı drama yöntemiyle performans çalışması için buluşma, 12 Şubat 2013 Salı günü iki farklı grubun gönüllü bir kişinin evinde pankart hazırlaması yer ald1.

Son toplantı sonrası tüm gönüllüler yoğun bir çalışma temposuna girdiler. Bir yandan performans hazırlığı yapılırken bir yandan pankartlar hazırland1. Aynı zamanda etkinlik haberleri, sosyal medyada, basında, radyoda duyurulmaya devam etti. Radyo ODTÜ üç gün (12-13-14 Şubat 2013) boyunca, en çok takip edilen programlarından birisi olan sabah kuşağında (10.00-12.00 arası) etkinliği duyurdu.

Etkinlik programına dâhil edilen performans için 11 Şubat günü, ODTÜ’nün bahçesinde altı kişilik bir grup bir araya geldi. Yapılan atölyede, etkinlik teması üzerine konuşuldu. İstatistikî verilerin ve gruptaki katılımcıların daha iyi bir dünya için dileklerinin yer alacă̆ 1 bir performansta karar kılındı. "Katil Köpekbalığı” ve "Kutu Kutu Pense” oyunlarının yapısı performansın biçimini belirledi.

Katil Köpekbalığı oyununda, etkinlik yerinde izleyicilerin oluşturduğu çemberin içinde dolaşan performansçılardan katil olanı, göz göze geldiği diğer bir performansçıya göz kırptı̆̆ında o kişi birkaç saniye sonra olduğu yerde durdu. Kadın cinayetlerine dair istatistikî bir veri aktarıp çığlık atarak yere kapandı. Beş kişi verileri aktarıp yere düşene kadar performans devam etti.

Performansta aktarılan istatistikî veriler;

- "Kadın cinayetleri son yedi yılda \% 1400 arttı."

• “Öldürülen beş kadından üçü, kocası tarafindan katlediliyor.”,

• “Öldürülen kadınların \% 40’1 kesici aletlerle katlediliyor.”,

• “Öldürülen kadınların \% 30’u boşanmak istediği için katlediliyor.”,

- "2008-2012 y1lları arasında 700 kadın yakınları tarafından katledildi."

Erkek performansçı yere düşen kadınlardan birinin elinden tutup onu kaldırdı, ayağa kalkan, bir diğerini kaldırdı. Böylece tüm performansçılar ayağa kalkıp çember oldular ve dönerek şarkı söylemeye başladılar: "Koca koca dünya/gözlerini açsa/insanların hepsi sözlerimi duysa!" Her tur sonrasında bir kişi, çemberden çıkıp önceden belirlediği yöne giderek dileğini söyledi ve bu dileğini temsil eden bir imge içinde dondu. Altı kişi de donduğunda performans sona erdi.

Performansta söylenen dilekler:

- Tercihlerimden dolayı, ailem ve yakın çevrem tarafından onaylanmak istiyorum.

- Bana ne giyeceğimi değil, oğullarınıza taciz etmemeyi öğretmenizi istiyorum. (Bu cümleyi söylerken performansçı, eteğini yavaş yavaş yukarı çekerek taytın üzerine yapıştırdığı yazılarla, etek boyunun uzunluğuna göre, bir kadının toplum tarafından nasıl algılandığını gösteren bir grafik aktardı) 
- Kızımın huzur içinde yaşayacağı bir toplum istiyorum.

- Çocuk gelinler olmasın istiyorum.

- Bütün kizlar okula gitsin istiyorum.

- Kadın olmadan önce insan olmak istiyorum.

12 Şubat 2013 Salı günü pankart yapımı için toplanıldı. Gönüllüler uygun oldukları saat diliminde gelip pankart yapımına yardım ettiler. Kartonlar, çıtalar, renkli kartonlar, keçeli kalemler, rengârenk boyalarla, bantlarla pankartlar hazırland1.

\section{Pankartlara yazllan sloganlar :}

1. Asıl suçlu, ikiyüzlü olan ahlâkınızdır!

2. Kızını değil dizini döv!

3. Dans etmediğim devrim, benim devrimim değildir!

4. Dünya yerinden oynar kadınlar özgür olsa!

5. DANSLI DEVRIM bunun adi!

6. Ev işlerini Marslılar yapsın!

7. Gücünüz 1 milyar kadına yetsin!

8. Şiddeti ben doğurmadım!

9. Sen bağır ki şiddet sussun!

10. Bazı danslar şiddetlidir!

11. Kur zincirleri!

Pankartların yazıldığı akşam saat 18.30 'da IMC TV'de grubumuzdan bir gönüllü canlı yayına katıldı ve "Kadına, kız çocuklarına yönelik şiddete, tacize, tecavüze, enseste, seks köleliğine, kadın sünnetine karşı dur" demek için izleyicileri "Bir milyar Ayaklanıyor!" etkinliğine davet etti. Sorulan soruları cevaplayarak kampanyanın içeriği, günü ve saati hakkında tekrar bilgi verdi.

Etkinlik günü çalınacak şarkılar organizasyon sayfasında önerildi. Önerilen şarkılardan oluşan bir liste hazırlandı ve şarkılar oylama ile seçildi. Oylama sonucunda "Bir Milyar Ayaklanıyor" resmi şarkısı yanı sıra kadını, şiddeti (emeği sömürülen kadın, kız çocuğu, çocuk gelinler), mücadeleyi, birlikteliği anlatan şarkılar (Bandista- İsyan gibi) seçildi.

\section{Etkinlik Günü}

Etkinlik günü saat 10.00 'da yara ve yanık makyajları Azin Mokhtari tarafindan, belirlenen kişilere yapıldı. Yüzü yanık, yanağı kesik, burnu kırık, gözleri morarmış, alnı şişmiş kişiler eylem noktasına doğru yola çıktı. Eylemde tencere, tava, kepçe, tencere kapağı gibi çok ses çıkaran mutfak gereçleri ve düdük kullanıldı. Ses sistemi hazırlandı. Çalınacak şarkılar sıralandı. Pankartlar taşındı. Bez afiş asıldı. Simurg Kuşu meydanın ortasına koyuldu. Gözleri kan ağlayan adalet tanrıçasını temsil eden ve her işe koşan çok kollu kadını temsil eden, yüzleri metal rengine boyanmış, kıyafetleri metalik renkte canlı heykeller performanslarını sergilediler.

Saat 12.00 'de müzik başladı. Gruptan bir kişi etkinliği ve süreci yönetti. Kampanyanın önemine dair açıklama yaptı. 12.30'da basın bildirisi okundu. CHP Ankara milletvekili Aylin Nazlı Aka, kadına yönelik şiddete karşı konuşma yaptı. Konuşma sonrası kampanyanın resmi şarkısı "Kır 
zincirlerini”" (Break the Chain) ile daha önceden provalara katılan kadın ve erkekler üzerlerinde "Bir milyar ayaklanıyor" baskılı polarlarla meydanın ortasında dans ettiler. Polar satın almamış olup da dansa katılanlar rengârenk giyindiler. İki kez aynı koreografi ile dans edildikten sonra, kadın temalı şarkılar çalındı. Etkinliği izleyenler gönüllüler tarafindan çembere çekildi ve onlarla dans edildi. Yaratıcı Drama yöntemiyle hazırlanan performans, halkın dans etmesinin hemen ardından başladı. Hazırlanan koreografiyle halk yeniden dans etti. Simurg Kuşu'nun ağzındaki kurdeleye yazılan notlar toplu iğne ile tutturuldu. Yazılıp asılan yazılar okundu. İzleyiciler kendini ifade etme firsatı buldu.

\section{Etkinlik Sonrası}

Etkinlik sona erdiğinde, etkinliğin gerçekleştirildiği sokak toplandı. Ardından organizasyon grubu bir toplantı yaptı. Kadınların yazdıkları yazılar yeniden okundu. Gönüllüler, etkinliğe katılanların kendileriyle paylaştıkları hikâyelerini anlattılar. 2014 yılı için neler yapılabileceği konuşuldu. Kalan çekirdek grubun irtibatının devam etmesi amacıyla Facebook sayfasında yeni bir grup kuruldu. İhtiyaç duyulan her şeyi ucuz ürün satan bir milyoncu mağazalarından alan gönüllüler, yeni grubun adını da "bi' milyoncular" koydular.

\section{Bulgular ve Yorum}

\section{Gözlemlere İlişkin Bulgular}

\section{a. Etkinlik Öncesi Gözlemleri}

Ankara etkinlik gönüllüleri ilk toplantıda 5 kişiyken, ikinci toplantı itibariyle 15 kişi olmuşlardır. Bu artışta sosyal medyanın etkisi büyüktür. Paylaşılan etkinlik sayfası gittikçe daha fazla kişi tarafından görülmüş, paylaşılmış, üzerine konuşulmuş ve gönüllülerin sayısı artmıştır.

Gönüllülerle sorunsuz görev dağılımı yapılmış ve iyi bir işbirliği yaşanmıştır. Yalnızca emniyetten izin almak gerektiğinde gönüllüler çekince çekinmişlerdir. Düşünce özgürlüğü sebebiyle yaşanan tutuklanmaların halkın üzerinde oluşturduğu baskıdan dolayı sessiz kalmaların yaşandığ düşünülmüştür.

Sosyal medya aracılığı ile erişilen gönüllüler, sayfada paylaşılan iletileri hemen görmüşler ve yanıt vermişlerdir. Özellikle etkinliğin yaklaştığı son günlerde birkaç saniye içerisinde görüp, görüş bildirmişler ya da kendileri önerilerde bulunmuşlardır. Etkinlik, gönüllüler aracılığıyla Facebook, Twitter gibi sosyal medya üzerinden yoğun bir şekilde duyurulmuştur. Bu durum, etkinliğe olan inancın ve teknolojinin hizının sonucudur.

Etkinlik esnasında ihtiyaç duyulan malzemeler, gönüllülerin kendi aralarında para toplamalarıyla karşılanmıştır. Ayrıca etkinliğin duyurulması ile afiş, broşür basımı için çeşitli kurumlardan destek alınmıştır.

Etkinliğe maddi manevi destekte bulunanlar: Çankaya Belediyesi, Milletvekili Aylin Nazlıaka, Türk Mühendis ve Mimar Odaları Birliği (TMMOB), Makine Mühendisleri Odası, Ankara Sine-i Sanat Atölyesi (ASSA), Tish-o, Kaos Gey ve Lezbiyen Kültürel Araştırmalar ve Dayanışma Derneği (Kaos GL), ODTÜ Mezunları Derneği, AEGEE - Ankara, Yaşam Alanı Derneği (YAŞAD), Tüm Kadın Lobisi Derneği (TÜKAL), Cinsel Şiddete Karşı Kadın Platformu, Kültürlerarası Araştırmalar Derneği, İRİS Eşitlik Gözlem Grubu, Uçan Süpürge, Feministbiz, Karçiçeği Bale ve Dans Okulu, Radyo ODTÜ. 
Etkinliği duyurmaya yardımcı olanlar: Hürriyet gazetesinin Ankara eki, Sanatçı Aynur Doğan, Gazeteci ve yazar Ece Temelkuran, Bianet, Radikal (Senden Haber), Milliyet Blog, METU Events, Erkek Muhabbeti, Salkım Sögüt, Nüve, Madam Brownie, Pucca Fan Club, İstapin, Genç Düşünce Toplulukları.

\section{b. Etkinlik Günü Gözlemleri}

14 Şubat 2013 günü başlayan etkinliği iki saat boyunca ortalama 4000 kişi ziyaret etmiş; hem kadın hem de erkek katılımcıların olduğu etkinliğe, düşünülenden fazla erkek katılmıştır. Etkinliğe bilerek gelenlerin yanı sıra etkinliği yoldan geçerken görüp izleyenler de olmuştur. Etkinliği izleyenler, yalnızca izlemekle kalmayıp dans da etmişlerdir. Karanfil Sokak’ta işyerlerinde çalıştıkları için etkinliğe katılamayanlar, pencere ve balkonlara çıkıp etkinliğe destek vermişlerdir.

Birden fazla basın yayın organı etkinlik esnasında hazır bulunmuş, kampanyaya ilgi göstermiştir. Gönüllülere kampanya ile ilgili sorular yönelterek onlarla röportaj yapmışlardır. Etkinliği, televizyonda canlı yayında göstermişlerdir.

Etkinliğin verdiği cesaretle Simurg kuşunun kurdelesine yaşadıklarını yazıp tutturan kadınlar olmuştur. Böylece etkinlikteki kadınlardan bazılarının aile içinde şiddete maruz kalmaya devam ettikleri tespit edilmiştir. İki saatlik etkinlik sonrası yazılanlar açıkça göstermektedir ki sesini çıkaramayan kadınların cesaretlendirilmeye ihtiyacı vardır. Yazılan yazılardan bazıları aşağıda yer almaktadır.

\section{Dilekler}

- Kız çocuklarının okutulmasını istiyorum.

- Sınıfsız, sınırsız, sömürüsüz yeni bir dünya istiyoruz!

- Kuma olmak istemiyoruz.

- Kisitlanmak istemiyoruz!

- Kararlarımızı özgürce verdiğimiz yeni bir yaşam...

- Sokakta rahatça dolaşmak istiyorum!

- Çocuk gelinlere hayır!

\section{Şiddet Mağdurları}

- Baba beni rahat birak...

- Babam artık anneme fiziksel ve psikolojik şiddet uygulamasın istiyorum. Artık babam da insan olsun istiyorum!

- Ben şiddete uğrayan ve tehdit edilen bir kadınım. Kendi olanaklarımla ayakta durmayı başardım!

- Baba, anneyi dövünce hem o kadına hem de dayağı duymasın diye başını yastığın altına koyan çocuğa yazık!

- Genelevden yüzlerce kadın çıkardım. Kadın satışına hayır!

- Ben şiddet mağduruyum üst bürokrat eşi olarak, istemiyorum! 
- Boşandığım halde bana psikolojik ve fizyolojik şiddet uygulamaya devam eden kocamın Allah belasını versin!

- Canımı acitmak sana zevk vermiyor, yapma!

\section{Toplumsal tespitler}

- Sokakta öpüşürken tepki verirler, dövülürken görmezler; çünkü değer yargılarınız var!

- Bu kadar erkek bakanın içinde neden bir kadın bakan var? Kadınlar bakanlık için yeterince zeki değil mi?

- Erkeklerle aynı işte çalışıyoruz, peki neden daha az kazanıyoruz?

- Kadınlara sonsuz mutluluk için, özgür dünyanın tüm bireyleri, hadi ayaklanın!

- Şiddet gören kadınlar yerine, şiddet uygulayan erkekler gözetim altına alınsın!

- Gereksiz meselelerden bahseden meclisin, her gün bir kadının dövülerek öldürüldügü bir ülkede, bunu hiç konuşmaması, bu ülkede en çok kadınların ayrıma uğradığını gösteriyor.

- Avrupa’yı 10 yıldır bir kadın yönetiyor. Bizim ülkemizde kadınların işgücüne katılma oranı kaç?

- Tüm dünya kadınları toplumsal cinsiyet illeti ve maruz bırakıldıkları ayrımcılık ve şiddet zincirlerinden kurtulacak!

- Patriarkaya, heteroseksizme, militarizme, toplumsal cinsiyete hayır!

- İkiyüzlü geleneklere hayır!

- Anneler erkek çocukları sizin eseriniz! İyi yetiştirin, sevgiyle büyütün!

\section{Diğerleri}

- Arzu da benim, beden de!

- Şiddetin haklı gerekçesi olamaz!

- Feminizm herkes içindir.

- Vajina!

- Erkeksiz hayat, oh ne rahat!

- Erkeklerin milli olmalarıla övünmediği bir dünya...

Etkinlikte gönüllülerin dans ettikleri katılımcılardan bazılarının, maruz kaldıkları şiddet olaylarını gönüllülerle paylaştıkları tespit edilmiştir. Bu olaylardan birinde katılımcı, gönüllü ile dans ederken, eski eşinin yüzünü bıçakla yaraladığını, kendisinden boşanmak istediği halde zorluk çıkardığını, fakat mücadele sonucunda boşanmayı başardığını ve şu an sevdiği bir insanla mutlu bir hayat sürdüğünü anlatmıştır. Yolda karşılaştığınız ya da otobüste yan yana oturduğunuz bir kadın, şiddete maruz kaliyorsa, bu durumu dile getir(e)mez. Fakat kampanya sayesinde sokaktan geçen bir kadın yaşadığı şiddeti ve bu şiddetle nasıl mücadele ettiğini anlatabilir.

Etkinliğin sonunda konuşmak isteyen vatandaşlara mikrofon verilerek kadına yönelik şiddete karşı düşüncelerini anlattıkları özgür bir platform sunulmuştur. İngiltere'de, Hyde Park’ta bulunan 
speakers' corner' dan ${ }^{5}$ esinlenerek oluşturulan geçici köşede, birkaç saniyeliğine de olsa vatandaşlar seslerini duyurabilmişlerdir.

Yaratıcı drama yöntemiyle kadın cinayetleri hakkında istatistikî veriler aktarılmış, bir nevi belgesel tiyatro izleri taşıyan bir performans sergilenmiştir. $\mathrm{Bu}$ verilerin bir performans içinde aktarılması, verileri hem kalıcı hem de etkili kılmıştır. İzleyicileri düşünceye sevk etmiş ve aktif izleyici konumuna sokmuştur.

İkinci bölümde ise, Rahibe Teressa'nın “Savaşa karşı eylem yapacaksanız gelmem; ama barış için eylem yapacaksanız gelirim.” düşüncesinden yola çıkılarak yalnızca olumlu dileklerin aktarılması uygun görülmüş ve söylenen cümleler hep "istiyorum” ile bitmiştir. İzleyicilerin de zihinlerinde olumlamaların olması hedeflenmiştir.

Dans ve yaratıcı drama yöntemiyle yapılan performansın yanı s1ra, canlı heykel performansları sergilenmiş, gözleri kan ağlayan adalet tanrıçası Themis, her işe koşan çok yönlü (çok kollu) kadın, sokak sanatı icra eden, toplumsal yaşantı içindeki olayları eleştiren ASSA'nın şiddete karşı bakış açısını yansıtmıştır.

\section{c. Etkinlik Sonrası Gözlemleri}

Etkinlik sonrası kişisel ve kurumsal tebrikler alınmıştır. Bu tebriklerden bazılarına aşağıda yer verilmiştir:

“Tebrikler çok güzel organizasyondu. Ben de Kütahya'dan geldim..."

"Sevgili arkadaşlar, bu etkinliğin gördüğüm en başarılı gönüllü organizasyonlardan biri olduğunu belirtmeden geçemeyeceğim. Kısa zamanda epey iş başardınız, harikasınız!"

"Çok güzel bir gün oldu bir sürü kadın toplandı sizin organizasyonunuzla. Hem de herkesi birleştirip dans ettirdiniz çok güzeldi."

"Selam, herkesi kutlarım çok başarılıydı. Fazla destek olamadıysak da Yaşam Alanı Derneği sayfasından anlık foto ve video paylaştık. Bu ekibin YASAD' da bir kadın çalışma grubu oluşturup çalışması bizim için onur verici olur. Sevgiler!"

“Çok başarıl1, etkili ve güzel bir organizasyon gerçekleştirdiniz. Verdiğiniz emek çok büyük. Sonsuz tebrikler. Her zaman yanınızdayız..."

Bu kampanyaya katılıp birbirini hiç tanımadan bir araya gelen ve Ankara ayağını organize eden gönüllüler, patriarkalın hâkimiyeti karşısında ezilen kadınların sesini duyurmak istediler. Türkiye'de ve dünyada kadınların yaşadığı fiziksel, psikolojik, ekonomik şiddetin sonuçlarını ortaya koyup, şiddete karşı dikkat çekip, insanların eyleme geçmesini sağlamayı, toplumda farkındalık yaratmayı amaçladılar. Bu amaç doğrultusunda kampanya sonrasında çalışmalarına ve etraflarındaki kadınları bilinçlendirmeye devam etmektedirler. Grupta yer alan gönüllü avukatlar, Türkiye'nin her yerindeki kadın cinayetleri davalarına gitmekte ve hayatı son bulan kadınları savunmakta ve işlenen suçun cezasız kalmaması için mücadele etmektedirler.

Kampanya gönüllülerin sürece dâhil olma ve yalnızca 2013 y1lı için gönüllü çalışma istekleri organizasyon esnasında şu yönde değişiklik göstermiştir: "Organizasyonu seneye de devam ettirmeliyiz. Bir STK çatısı altında belki toplanmalı ya da yeni bir oluşum içine girmeli ve gönüllü sayımızı çoğaltarak bilinçlendirme sürecinin hızlanmasına katkıda bulunmalıyız."

5 http://de.wikipedia.org/wiki/Speakers\%E2\%80\%99_Corner, Erişim Tarihi: 04.11.2013 


\section{Sonuç ve Öneriler}

Kadının içinde bulunduğu toplum düzeninde maruz kaldığı şiddet içeren tavır, davranış, söylem ve eylemler üzerine yapılan bilinçlendirme çalışmalarında dinleyici olarak pasif kalan gönüllü kadınlar, "Bir milyar ayaklanıyor" kampanyasıyla aktif olma, seslerini çıkarabilme firsatı buldular. Ayrıca kampanya ile yeni bir öğrenme ortamı oluştu. Nasıl örgütlenilir? Demokratik bir örgütlenme için neler yapılması gerekir? Grup çalışması nedir? İşbölümü nasıl yapılır? Gönüllü katılımcılar bu soruların cevaplarını yaşayarak öğrendiler.

Toplantılarda ve eylem sürecinde oluşan ortam, sosyalleşmeyi beraberinde getirdi. Aynı amaç için çalışan insanlardan oluşan gönüllüler arkadaşlar oldular. Maruz kaldıkları şiddetle nasıl başa çıktıklarını birbirlerine anlatarak birbirlerine destek oldular. Herkesin kendini ifade ettiği ve dinlendiği bir ortama sahip oldular. Buldukları yaratıcı sloganları pankartlara farklı yazı biçimleriyle yazıp, sloganların zihinlerinde oluşturduğu imgeleri resmettiler. Yaratıcı drama ile hazırlanan performansta, bireysel olarak kendi düşüncelerini ve isteklerini ifade etme olanağ

Etkinlik günü, Karanfil Sokak’a gelen kadınlar, kadınların örgütlendiklerini; yaşadıkları şiddetin yalnızca kendilerine özgü olmadığını, şiddete maruz kalan diğer kadınların seslerini duyurabildiklerini gördüler. Kendilerinde de güç bulup etkinlik sonunda eline mikrofonu alıp konuşan ya da duygularını kâğıda döken kadınlar kendilerini ifade etme fırsatı buldular. Kadınların yaşadığı şiddetin istatistikî verileri nelerdir? Kampanya gönüllüsü kadınlar neler istiyor? gibi soruların cevaplar1 yaratıc1 drama ile hazırlanan performansta aktarıld1.

Bu kampanya hem kampanya gönüllüleri hem de katılımcıları için yeni bir öğrenme ortamı oluşturdu. Gönüllüler süreçte, katılımcılar sokakta öğrendiler. Bu kampanyanın yaratıcılık, kendini ifade etme ve sosyalleşme gibi konularda fayda sağladığ 1 görüldü. Bu sebeple gelecek yıllarda da kampanyanın devam ettirilmesi gerektiği düşünülmektedir.

Bu kampanyada, sosyal medya üzerinden birbirini tanımayan kişiler tıpkı Arap Bahar'ındaki gibi örgütlendi. Sosyal medyanın halkların örgütlenmesi üzerindeki etkisi doğrudan yaşandı. Her yaştan, her görüşten, farklı meslek gruplarından bir araya gelen gönüllülerden oluşan istekli grup, oluşturduğu sinerji ile yaklaşı bir ay gibi kısa bir zaman dilimi içinde bu etkinliği gerçekleştirdi. Gönüllüler gece gündüz ayrımı yapmadan çalıştılar ve istekleri gönüllülerin birbirini motive etmelerini sağladı.

$\mathrm{Bu}$ ve benzeri kampanyaların organizasyonunda, gönüllülerin fikir birliğine varmaları ve birlikte karar vermeleri önem kazanmaktadır. Bireylerin bir bütünün parçası olduğunu unutmadan tek başına hareket etmemesi gerekir, aksi halde grup uyumu bozulur. Ayrıca aynı amaç için bir araya gelen bireylerin, din, dil, cinsiyet, ırk, ideoloji ayrımı yapmaksızın çalışması gerekir. Etkinlik günü dışarıdan belirlenen temanın dışında farklı konuların ortaya atılarak etkinliğin amacının saptırılmasına karşı önlem almak gerekir.

“Bir milyar ayaklanıyor!” kampanyası tüm Türkiye'de yankı uyandırdı. Kadınlar işyerlerinde, mecliste, sokakta, evde, meydanlarda v.b. dans ettiler. Televizyonlarda canlı yayında kampanyanın haberleri yapıld1. Gazeteler günlerce kampanyayı yazd1. Erkekler kampanyaya destek verdi. toplum kuruluşları Kuruluşları kampanyaya destek verdi. "Şiddet” kavramı yeniden gündeme geldi. 
Tüm dünya kadına ve kız çocuklarına uygulanan şiddete karşı harekete geçmiş olsa da kampanya geniş kitlelere; kadınların, kız çocuklarının ve LGBTİ bireylerinin yaşadığı zulmü, haksızlığı, cinayeti, tecavüzü duyurmuş olsa da ne cinayetler, tecavüzler, işkenceler ne de seks işçiliği bitmiyor. Kadınlar hâlâ işyerinde erkeklerden daha az kazanıyor. Ev işleri hâlâ kadınların omuzlarında yük olmaya devam ediyor. Kadınlar hâlâ cinsel obje olarak görülmeye devam ediyor. Bu nedenle bu kampanyanın mevcut hükümetlere yapacağı baskı ile yaşanan fiziksel, psikolojik, ekonomik şiddete karşı daha fazla yaptırım uygulatması, cezaların arttırılması ve halkın bilinçlenmesi için okullarda ve okul dışında eğitimler verilmesi gerekmektedir. Toplumun en küçük birimi olan ailede, çocuklarını yetiştiren anne babanın ve yarının yetişkinleri olacak çocuklar ile gençlerin bilinçlendirilmesi, eğitilmesi, bilgilendirilmesi ve desteklenmesi için çözümler üretilmeli ve programlar geliştirilmelidir.

Kampanya önümüzdeki yıllarda da yapılmalı ve bilinçlendirmeye, birlik olmaya çağırarak yaşanan şiddete son verene kadar devam etmelidir ki; V-Day 2014 yılı başlığını açıklamıştır. 14 Şubat 2014 tarihinde "Bir milyar adalet için ayaklanıyor!". Dünyada çığ gibi büyüyen adaletsizliğin sonucu olarak kadınlara uygulanan şiddet de aynı oranda artıyor. Birbirini seven ve destekleyen insanlar bir araya gelip mahkeme, hükümet ya da okul binalarında, karakolda, çevresel adaletsizliğin olduğu yerlerde, elçiliklerde ya da kamuya açık alanlarda dans ederek adalet ve şiddet karşıtlığ 1 için küresel bir dayanışma örneği göstereceklerdir. ${ }^{6}$ Öfke, aşağılanma, acı, utanma, suçluluk ve kederden kurtulmak için yapılan bu çağrıya Ankara gönüllüleri cevap vererek organizasyonun Ankara ayağını bu yılda üstlenmişlerdir. Gönüllülerden bazıları bu yıl belirlenen tarihte yurtdışında yapılan organizasyonlara katılacak ve Ankara'daki gönüllülerle iletişim halinde olacaktır.

Dans, canlı heykeller, tiyatro, performans, gibi sanatla gerçekleştirilen eylemler, tüm dünya üzerinde yaşanan ve gittikçe artan şiddete karşı birlikte mücadele etmenin, dayanışma içinde olmanın, herkese çağrı yapmanın, sisteme karşı olmanın başka bir dilidir. Bu nedenle sanat ile verilen mücadelenin karşısında durabilecek bir güç yoktur. Sanatla kendini bulan birey, dünyaya adımını atar ve haklı olarak adaletsizliğe karşı mücadeleye başlar.

\section{Kaynakça}

Erbil, P. (2000). Kibele'den pandora'ya kadının tarihsel yenilgisi. Ankara: Arkadaş Yayınevi.

Goldman, E. (2006). Dans edemeyeceksem bu benim devrimim değildir. İstanbul: Agora Kitaplı̆̆ı.

http://www.youtube.com/watch?v=gl2AO-7Vlzk, Erişim Tarihi: 03.11.2013

http://www.youtube.com/watch?v=2TipNbv7-1Q\&hd=1, Erişim Tarihi: 03.11.2013

http://www.youtube.com/watch?v=c0T4AwAa4yI\&hd=1, Erişim Tarihi:03.11.2013

http://www.youtube.com/watch?v=6YWMOngOQuU\&hd=1, Erişim Tarihi: 03.11.2013

http://www.youtube.com/watch?v=fL5N8rSy4CU, Erişim Tarihi: 03.11.2013

6 http://www.onebillionrising.org/about/campaign/, Erişim Tarihi: 04.11.2013 


\title{
EK1
}

\section{One Billion Rising kampanyasının Türkçe şarkı sözleri:}

\author{
Söz: Tena Clark
}

Müzik: Tena Clark/Tim Heintz

\begin{abstract}
Giriş
Kollarımı gökyüzüne kaldırıyorum,/ dizlerimin üzerinde dua ediyorum./ Artık korkmuyorum!/ Kapıdan yürüyerek geçeceğim./ Yürü, dans et, ayaklan!/ Yürü, dans et, ayaklan!/ Hepimizin yaşadığı bir dünya görebiliyorum,/ Güvenli ve tüm baskılardan özgür./ Daha fazla tecavüz, ensest ve taciz yok./ Kadınlar sahip olunan bir şey (mülk) değildir./ Bana asla sahip olmadın, beni tanımıyorsun bile!/ Ben görünmez değilim, ben basitçe harikayım./ Kalbimi ilk defa ayaklanıyor hissediyorum,/Canlı, harika hissediyorum./ Dans ediyorum; çünkü seviyorum./ Dans ediyorum; çünkü hayal kuruyorum./ Dans ediyorum; çünkü yeterince şey yaşadım./ Çığlıkları durdurmak için dans et!/ Kuralları yıkmak için dans et!/ Acıyı durdurmak için dans et!/ Bunu altüst etmek için dans et!/Artık zinciri kırmanın zamanı,/ Kır zincirini!/ Dans et, ayaklan!/ Bu çılgınlığın ortasında ayağa kalkacağız./ Daha iyi bir dünya var, biliyorum./ Kardeşlerini al ve uzat elini her kadın ve her genç kıza./ $\mathrm{Bu}$ benim bedenim, benim bedenim kutsaldır/Daha fazla bahane yok, daha fazla taciz yok!/Bizler anneyiz, bizler öğretmenleriz./Biz güzel yaratıklarız./Dans ediyorum; çünkü seviyorum. /Dans ediyorum; çünkü hayal kuruyorum./ Dans ediyorum; çünkü yeterince şey yaşadım./ Çığlıkları durdurmak için dans et!/ Kuralları yıkmak için dans et!/ Acıyı durdurmak için dans et!/ Bunu altüst etmek için dans et!/ Artık zinciri kırmanın zamanı!/ Artık zinciri kırmanın zamanı!/ Dans et, ayaklan!/ Bu benim bedenim, benim bedenim kutsaldır./ Daha fazla bahane yok, daha fazla taciz yok!/ Bizler anneyiz, bizler öğretmenleriz,/ biz güzel yaratıkları./ Dans ediyorum; çünkü seviyorum./ Dans ediyorum; çünkü hayal kuruyorum./ Dans ediyorum; çünkü yeterince şey yaşadım./ Çığlıkları durdurmak için dans et!/ Kuralları yıkmak için dans et!/ Acıyı durdurmak için dans et!/ Bunu altüst etmek için dans et!/ Artık zinciri kırmanın zamanı!/ Kır zincirini,/ Kır zincirini!/(Koro tekrar)
\end{abstract}

